\title{
Economic Implications of Marketing Structure of Banana and Plan- tain Fruits for the Development of Rural Communities in Enugu State, Nigeria
}

\author{
Obetta, Angela Ebere', Obetta, K. Chukwuemeka ${ }^{2}$, Achike, Anthonia Ifeyinwa ${ }^{3}$ \\ ${ }^{1}$ Department of Agricultural Economics, University of Nigeria, Nsukka, Enugu State, Nigeria \\ ${ }^{2}$ Department of Adult Education and Extra-Mural Studies, University of Nigeria, Nsukka, Enugu State, Nigeria \\ ${ }^{3}$ Department of Agricultural Economics, University of Nigeria, Nsukka, Enugu State, Nigeria
}

\begin{abstract}
There is increase in the level of purchase and consumption of banana and plantain due to their nutritional requirements. This led to increase in the number of market dealers on banana and plantain. Therefore, the study assessed the marketing channel and structure of banana and plantain in Enugu State, Nigeria. Adopting a descriptive survey design, copies of the instrument were administered to 160 banana and plantain sellers. Collected data were analyzed using descriptive statistics and Gini co-efficient. The results showed that majority of the respondents were married females who attained primary education. Majority of the wholesalers obtained their products directly from farmers while $71.80 \%$ of the retailers obtained from the wholesalers. The results of the Gini co-efficient for banana and plantain sellers showed low levels of inequitable distribution of income among them. However, inequalities existed more at retail level than at the wholesale level. Recommendations included that international donor should provide links between prospective banana and plantain farmers, policy makers and researchers to identify and analyze new ways of encouraging the market for mutual co-operation and structure for an effective banana and plantain marketing system.
\end{abstract}

Keywords: Rural development; Marketing; Marketing channels; Market structure; Income; Gini co-efficient

\section{Introduction}

Three out of every four people in developing countries live in rural areas. Ashley and Maxwell (2001) stated that rural area is a space where human settlement and infrastructure occupy only a small share of the landscape; where natural environment is dominated by pastures, forests, mountains and deserts; where settlements are of low density (about 5 - 10,000 persons); and places where most people work on farms ${ }^{[1]}$. According to Food and Agricultural Organization, FAO (2000), the definition of a 'rural area' should meet two criteria: one related to place of residence and land settlement pattern, and the other related to the type of work that residents engage in ${ }^{[2]}$. First, rural areas are generally open areas, with low settled population densities. A high proportion of the unsettled land area and/or land used is for primary production (mining, agriculture, livestock, forestry, fisheries). Second, the residents of rural areas are largely dependent - either directly or indirectly - on these primary production activities as their principal, if not their only, source of livelihood (Atchoarena\&Gasperini, 2003) ${ }^{[3]}$. Therefore, rural area is a place where availability of land is at a relatively low cost; and, where activities are affected by a high transaction cost, associated with long distance from cities and poor infrastructures among others.

In Nigeria, rural population is found in more than 97,000 rural communities. Their lives are characterized by misery, poverty, morbidity and under-development (Ekpo\&Olaniyi in Obetta\&Okide, 2011a) ${ }^{[4]}$. Hence, most Nigerian rural areas are characterized by low income, low savings (derived from low income), low investment (derived from low savings), low capital formation (derived from low investment), poor infrastructural facilities, high population density, gross illiteracy, low social interaction, local politics, under-employment, informal groups, high rural-urban migration, and low technological base (Obetta\&Okide, 2011b) ${ }^{[5]}$. It is pertinent to note that in Nigeria, rural development scope encompasses agricultural set-up projects, rural water supply projects, rural electrification projects, rural feeder-road and

Copyright (C) 2018 Obetta, Angela Ebere et al.

doi: $10.18282 / \mathrm{ff} . \mathrm{v} 7 \mathrm{i} 1.96$

This is an open-access article distributed under the terms of the Creative Commons Attribution Unported License

(http://creativecommons.org/licenses/by-nc/4.0/), which permits unrestricted use, distribution, and reproduction in any medium, provided the original work is properly cited. 
maintenance projects, rural health and disease control projects, rural education and adult education campaign, rural telecommunication system and rural industrialization projects.

There is therefore a need for the development of the rural populace through improvement in the living standards of the rural populace who are mainly farmers. Ogidefa (2010) stated that the main concern of rural development is to bring about the modernization of rural society through a transition from traditional isolation to integration with the nation ${ }^{[6]}$. According to Obetta and Okide (2011b), rural development is the integrated approach to food production as well as physical, social and institutional infrastructural provisions with an ultimate goal of bringing about both quantitative and qualitative changes which result in improved standard of living of the rural population ${ }^{[5]}$. Therefore, rural development is concerned with the improvement of the living standard in the rural areas on a self-sustaining basis through transforming the socio-spatial structures of their productive actives. It therefore infers that agricultural development is a component of rural development as more than two-third of the Nigeria's 150 million citizens are farmers. This population depends on agriculture for their livelihoods (World Bank, 2007) ${ }^{[7]}$.

In Enugu State, like in most states of Nigeria, agriculture remains the chief food provider, employer of labour and foreign exchange earner. Agricultural products including banana and plantain contribute about 40\% of the GDP (Federal Ministry of Finance and National Food Reserve Agency, 2008) ${ }^{[8]}$. Banana and plantain (Musa Spp.) are among the major food crops in Enugu State (Obetta\&Taru, 2018) ${ }^{[9]}$. They are major sources of energy and iron for millions of people, both in rural and urban areas (Achike, Okoroafor,\&Mkpado, 2011) ${ }^{[10]}$. They contribute to food security and diversification of income sources in both rural and urban areas (Ajayi\&Mba, 2007) ${ }^{[11]}$. The importance of banana and plantain to the sustainability and maintenance of a healthy body and nutritional requirements for man has led to increase in the level of its purchase and consumption (Honfo, Tenkouano, \&Coulibaly, 2011) ${ }^{[12]}$. As such, marketing of the products has become pertinent so as to meet the needs of consumers and also to increase the income of producers and marketers in Enugu State.

Marketing of banana and plantain involves everything that happens between the farm gate and the consumers including processing, storage, assembling, wholesaling and retailing (Taleke, 2010) ${ }^{[13]}$. Banana and plantain marketing is one of the driving forces for economic development of the rural areas. Marketing has a guiding and stimulating impact on the production and distribution of banana and plantain products (Mussema, 2006) ${ }^{[14]}$. The transformation of the production system requires the existence of efficient market system that can transfer the products from the points of production to the required market at the least possible cost so as to improve the living standard of the rural dwellers (Lutez inObetta\&Taru, 2018 ${ }^{[9]}$. The process is referred to as marketing channel. Therefore, banana and plantain marketing channel is the various means by which the fruits move from the producers to the consumers.

In Enugu State of Nigeria, banana and plantain marketing channel is highly decentralized. The products are usually assembled at the local markets from where the wholesalers make bulk purchase of the products. Also, in urban areas of the state, the wholesalers sell to the retailers who in turn, resell in smaller quantities to the ultimate consumers. However, in the rural areas, there are no established large marketing facilities. Rather, wholesalers purchase directly from the farmers (Olukosi\&Isitor, 1990) ${ }^{[15]}$. Efficient and good marketing system can only operate where there is fully utilized good market structure (Adegeye\& Ditto, 1985) ${ }^{[16]}$.

Therefore, market structure according to Olukosi and Isitor (1990) is the feature of the market organization that changes the nature of competition and pricing within the market ${ }^{[15]}$. These characteristics include the number of buyers and sellers in the market, knowledge of the cost, price and market conditions among the banana and plantain marketers. This has led to increase in the number of market dealers on banana and plantain. However, Ayinde, Adewumi and Ojehomon, (2009) noted that the increase in farm output has not led to a corresponding increase in the earnings of the vast majority of farmers ${ }^{[17]}$. One of the factors responsible for the imbalance is a poorly developed agricultural marketing system for major food staples such as banana and plantain, leading to their high rate of spoilage, rise in product prices and poor exportation rate (Akinyemi, Aiyelaagbe\&Akyeampong, 2010) ${ }^{[18]}$. The marketers experience huge losses during marketing of banana and plantain. This poses a great challenge to its marketers who are constrained to offer it for sale at any price to avoid further spoilage. This affects the economic development of the area as the traders are hindered from making better decisions especially, in rural areas (Chukwu, 1997) ${ }^{[19]}$. 
The wide gap between rural and urban prices of banana and plantain in Enugu State weakens the farmers' morale thereby reducing banana and plantain productivity (Care in Ndaghu, Taru\&Isah, 2011) ${ }^{[20]}$. This invariably will affect the rural community development of Enugu State. Therefore, to increase banana and plantain production in the state, there is need to develop a more efficient marketing system with market information. This enables prices in one market to be transmitted to other markets, thus synchronizing price and improving the economic capabilities of the rural marketers of banana and plantain. This, in turn, improves the standard of living of the rural dwellers.

The study dwelt on the decision-making roles in banana and plantain marketing, and the pattern of marketing among wholesalers and retailers in both rural and urban areas of Enugu State, Nigeria. The level of marketing channel, structure as well as the speed of price adjustment among banana and plantain markets in Enugu State has not been fully investigated and documented. Hence, the study focused on the assessment of economic implications of marketing structure of banana and plantain fruits for the development of rural communities in Enugu State, Nigeria.

\section{Purpose of the study}

The general purpose of the study was to assess the economic implications of marketing structure of banana and plantain fruits for the development of rural communities in Enugu State. The specific objectives of the study were to:

a. describe the socio-economic characteristics of banana and plantain marketers in Enugu State;

b. ascertain the marketing channels of banana and plantain in Enugu State;

c. examine the structure of banana and plantain marketing system in Enugu State.

\section{Research questions}

The following research questions were formulated to guide the study:

a. What are the socio-economic characteristics of banana and plantain marketers in Enugu State?

b. What are the marketing channels of banana and plantain in Enugu State?

c. What are the structure of banana and plantain marketing systems in Enugu State?

\section{Methodology}

The study was carried out in Enugu State, Nigeria. Enugu State is situated between Latitudes $5^{0} 55^{\prime} \mathrm{N}$ and $7^{0} 08^{\prime} \mathrm{N}$ of the equator and longitudes $6^{\circ} 55^{\prime} \mathrm{E}$ and $7^{0} 08^{\prime} \mathrm{E}$ of the Greenwich meridian. Enugu State is the second poorest state out of the five states that make up the South-East Zone of Nigeria. The State is made up of 17 local government areas that are grouped into three agricultural zones, namely, Enugu-East, Enugu-West and Enugu-North Zones. The major food crops cultivated by farmers in the state include banana and plantain (Musa spp.), cassava, and yam among others.

The study adopted descriptive survey research design as the researchers used the information obtained from a sample of banana and plantain sellers in Enugu State to describe the level of marketing channel and structure of banana and plantain markets in Enugu State, Nigeria. The population for the study was 320 respondents comprising 160 banana sellers (60 wholesalers and 100 retailers) and 160 plantain sellers (60 wholesalers and 100 retailers). The sample was 160 respondents comprising 80 banana sellers (30 wholesalers and 50 retailers) and 80 plantain sellers (30 wholesalers and 50 retailers) in the three agricultural zones of the state.

Multi-stage sampling technique was used for the study. In stage one, the three agricultural zones in Enugu State were used as a sample. In the second stage, two local government areas were selected from each zone using simple random sampling technique. The local government areas were Awgu and Oji-River Local Government Areas (Enugu-West Zone), Enugu-North and Nkanu-West Local Government Areas (Enugu-East Zone), and Udenu and Uzo-Uwani Local Government Areas (Enugu-North Zone). In stage three, one market in each of the six local government areas were purposively selected because wholesaling and retailing of banana and plantain are more prominent there. The markets were Oye-Awgu and Afor-Ugwuoba Markets (Enugu-West Agricultural Zone); Eke-Agbani and Enugu New Markets (Enugu-East Agricultural Zone), and Eke-Nimbo and Afor-Obollo Markets (Enugu-North Agricultural Zone). The selected sample represented 50.00 per cent of the entire banana and plantain sellers in Enugu State.

The data for this study were obtained from primary sources using a structured questionnaire that has two sections. 
Section A was on the socio-economic characteristics of the respondents, while section B elicited information on the marketing structure. The questionnaire was face validated by three experts in research methods who made corrections and modifications on phrasing of the items, language level, its relevance to the problem and the objectives of the study. The researchers administered the questionnaire on 16 banana and plantain sellers in Awka North Local Government Area of Anambra State, Nigeria. This was done to test the reliability of the research instrument. Cronbach alpha procedure was used to obtain reliability co-efficient 0.79 ; showing that the result was high and the instrument was reliable. The researchers therefore administered 160 copies of the questionnaire to the respondents on their market days through direct delivery technique. The administration and collection of the instrument were done with the help of three trained research assistants. All the 160 copies were duly filled and returned.

Descriptive statistics such as frequency and percentages were used to realize specific objectives (a) and (b), while Gini co-efficient (GC) model was used to realize specific objective (c), which is the market structure of banana and plantain. GC was employed to ascertain the inequality that existed for the monthly sales income from banana and plantain. The GC model which was adopted to analyze the market structure of banana and plantain is a ratio with values ranging between zero and one. When the Gini co-efficient is zero, it implies perfect equality in the distribution (zero market concentration) and this implies a perfect competitive market; but when Gini co-efficient is one (1), it implies perfect inequality (high market concentration) which is a monopolistic market situation. A low Gini co-efficient indicates more equal incomes, wealth or product distribution, while a high Gini co-efficient indicates more unequal distribution. The formula for GC of retailers and wholesalers is shown below as:

$\mathrm{GC}=1-\Sigma \mathrm{PC}$

Where: $\mathrm{GC}=$ Gini co-efficient in per cent

$\mathrm{P}=$ Percentage share of banana and plantain sellers

$\mathrm{C}=$ Cumulative percentage of their income

\section{Results}

The socio-economic characteristics of banana and plantain wholesalers and retailers examined in this study include gender, marital status, age, household size, educational attainment, marketing experience, source of capital, access to telephone and source of market information. These were presented on Figure 1, Figure 2 and Figure 3.

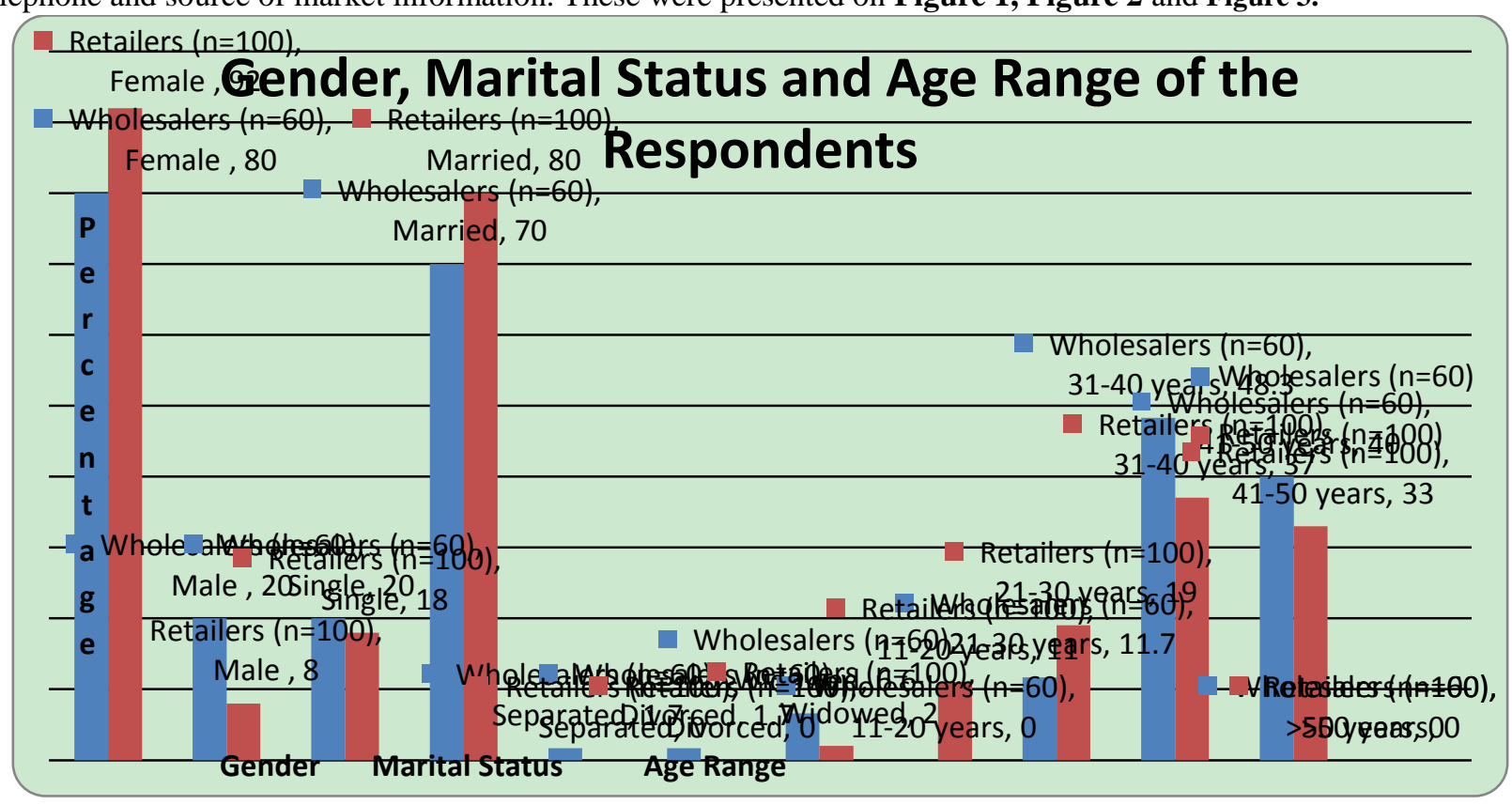

Figure 1. Socio-economic characteristics of respondents by gender, marital status and age

Figure 1 showed the gender, marital status and age of the banana and plantain wholesalers and retailers. In terms of gender, the data on the figure showed that females dominated banana and plantain wholesale and retail trade $(80.00 \%$ of wholesalers and $92.00 \%$ of retailers). The figure also showed that $70.00 \%$ of wholesalers and $80.00 \%$ of retailers 
were married. The implication is that a greater proportion of the respondents could have access to extra financial, moral and physical support from their spouses. This could boost their capital base. The figure further showed that most of the respondents (48.30\% of wholesalers and $37.00 \%$ of retailers) fell between 31 and 40 years of age. This implied that relatively most of the respondents were in their active age and they could do their business with youthful vigor.

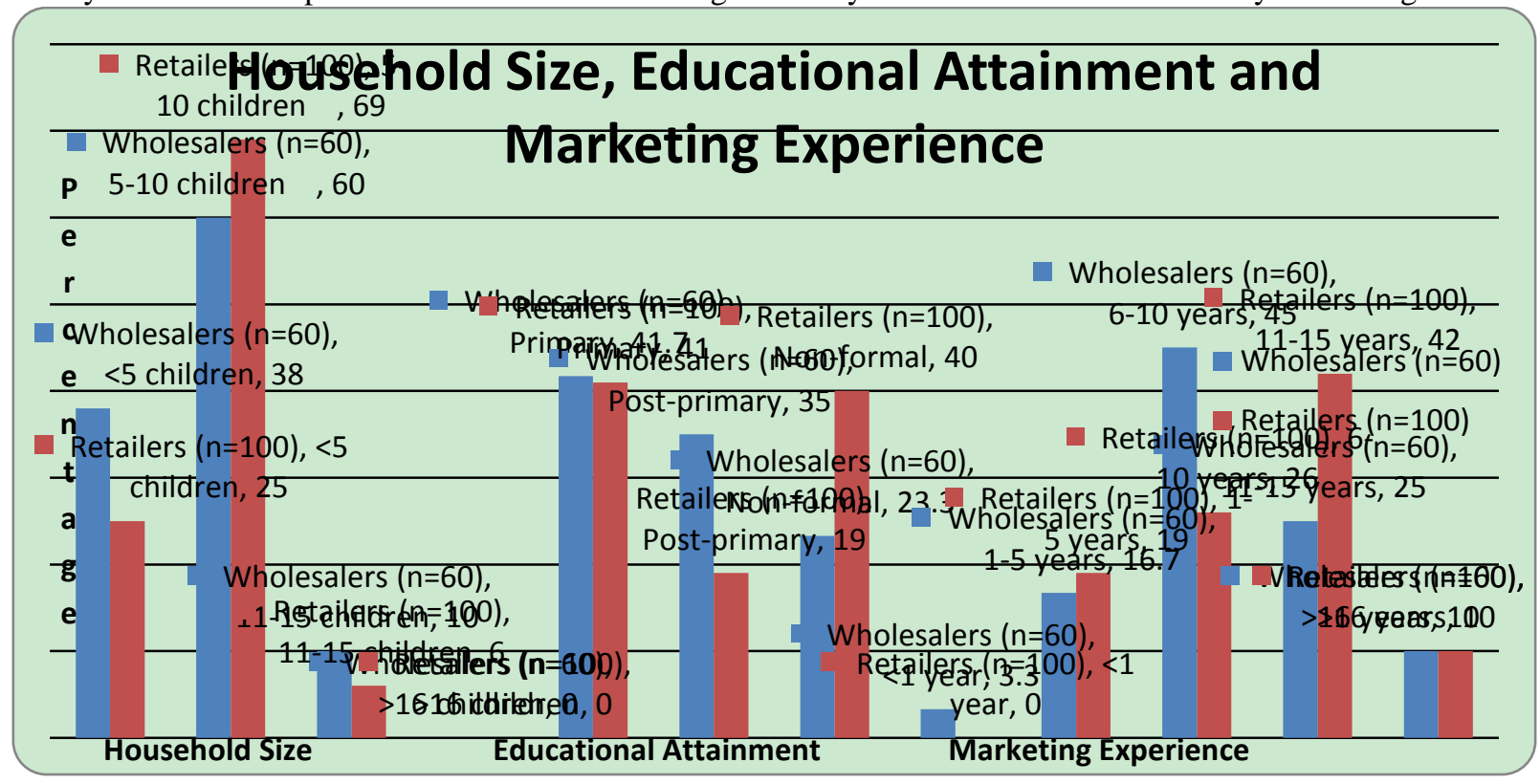

Figure 2. Socio-economic characteristics of respondents by household size, educational attainment and marketing experience

Figure 2 showed the household size, educational attainment and marketing experience. On household size, the figure revealed that majority of the marketers $(60.00 \%$ of wholesalers and $69.00 \%$ of retailers) had family size of 5 to 10 people. The findings implied that the higher the family size, the higher the tendency to get additional helping hands from other members of the household (especially, the children) and hence, the possibility of business expansion. The findings further showed that $41.70 \%$ of wholesalers and $41.00 \%$ of retailers had only primary education certificate implying that their low level of education hinders the keeping of accurate and reliable banana and plantain trading records. The findings of the study based on Figure 2 further showed that $45.00 \%$ of wholesalers and $26.00 \%$ of retailers claimed to have between 6 and 10 years of marketing experience while $25.00 \%$ of wholesalers and $42.00 \%$ of retailers claimed to have between 11 and 15 years of marketing experience. This implied that banana and plantain marketing continues to serve as quick and reliable source of income as many young people get involved in the marketing activities.

Figure 3 showed the sources of capital, access to telephone and sources of market information. The findings of the study based on the figure above indicated that the sources of capital to greater proportion of the marketers $45.00 \%$ of wholesalers and $49.00 \%$ of retailers) were personal savings while $36.60 \%$ of wholesalers and $32.00 \%$ of retailers obtain capital from co-operative societies. Also, out of 160 respondents, $86.60 \%$ of wholesalers and $82.30 \%$ of retailers have access to telephone. This implied that if properly informed, the acquisition of the telephone could boost the marketing of banana and plantain fruits. On the sources of market information, the figures showed that majority of the marketers (78.30\% of wholesalers and $60.00 \%$ of retailers) sourced their information from other marketers in the market, while the use of GSM was rated very low (16.70\% of wholesalers and $20.00 \%$ of retailers, respectively). This showed that there is neglect of some other sources of information such as GSM, radio/television and newspapers as sources of market information. 


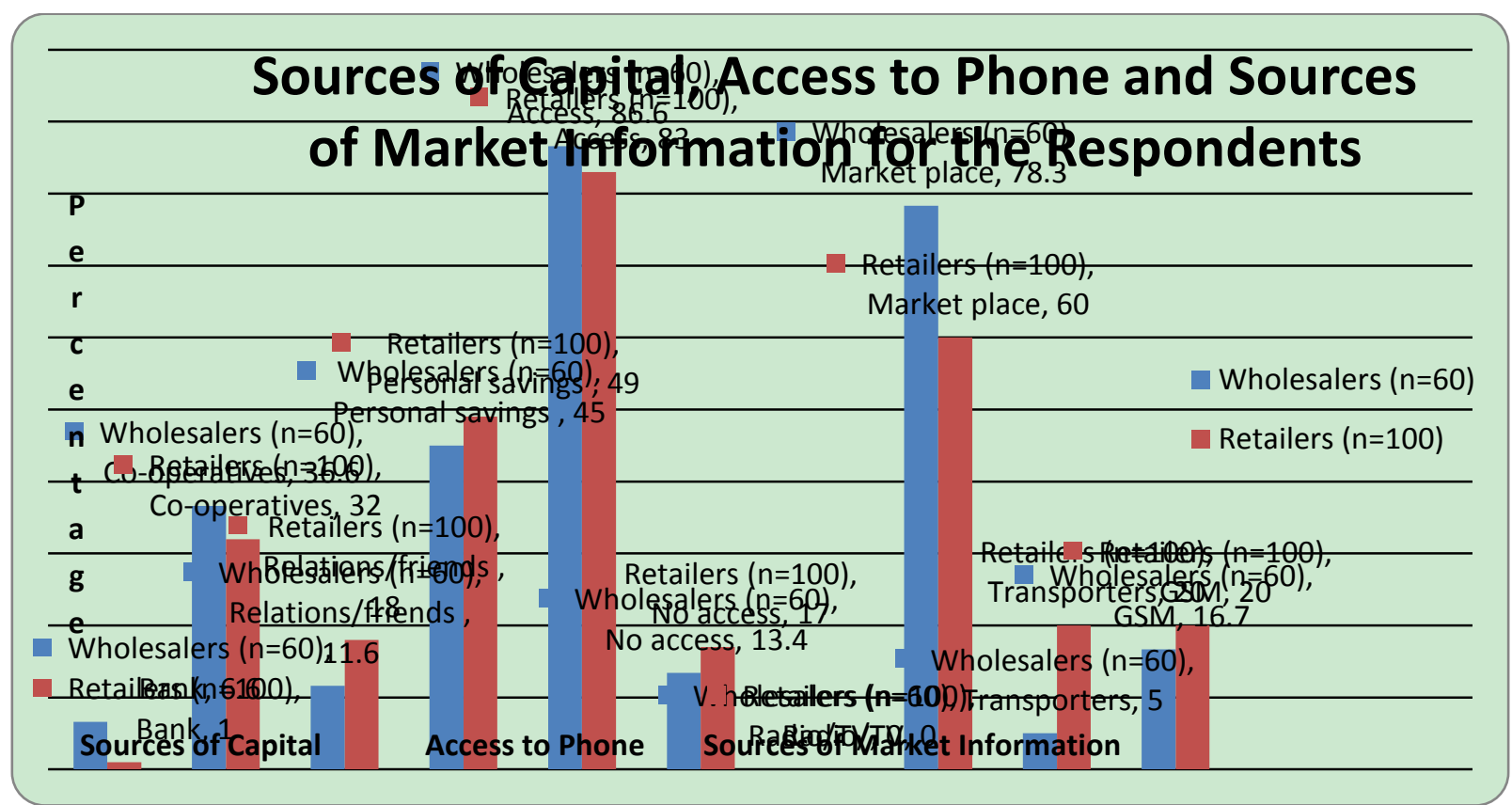

Figure 3. Socio-economic characteristics of respondents by sources of capital, access to telephone and sources of market information

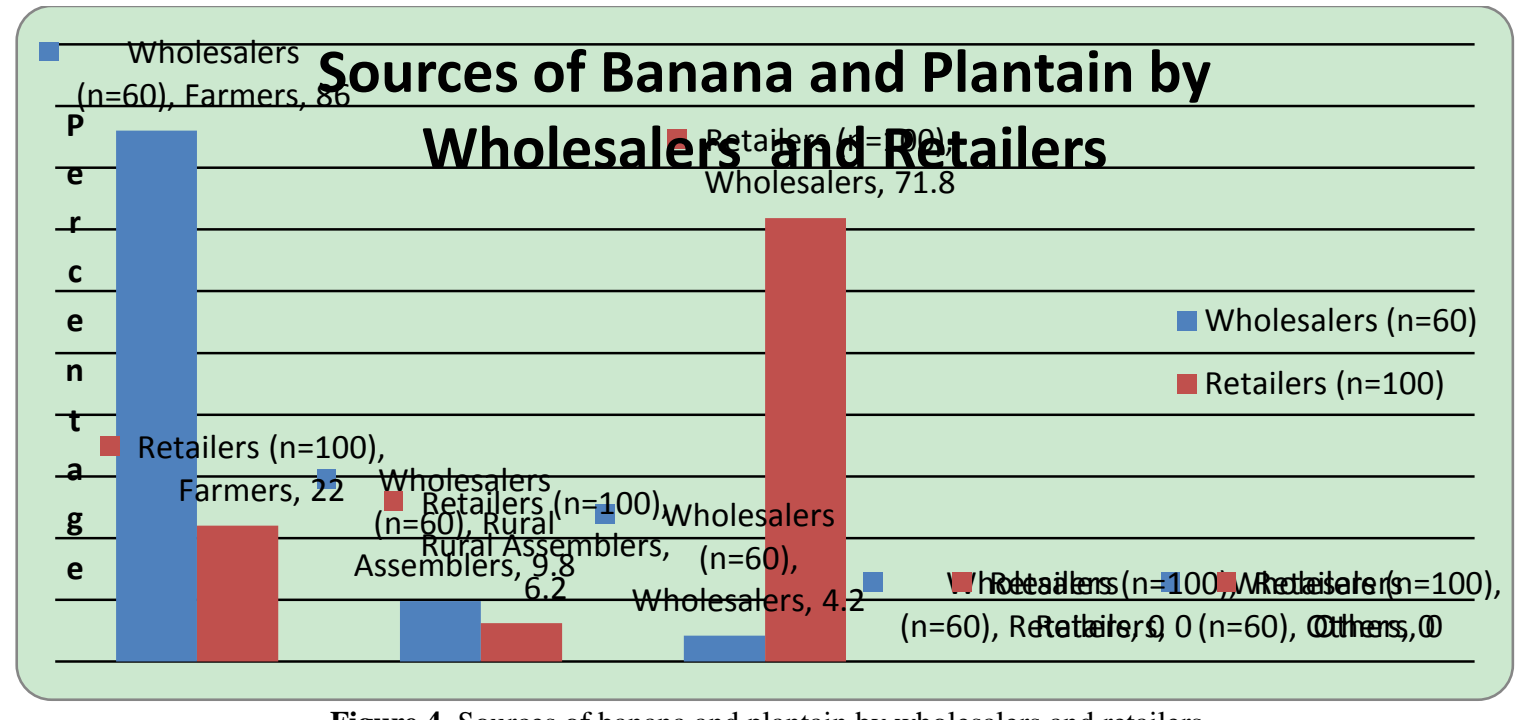

Figure 4. Sources of banana and plantain by wholesalers and retailers

Figure 4 showed that banana and plantain marketing channel in Enugu State is decentralized. The findings of the study implied that both the wholesalers $(86.00 \%)$ and retailers $(22.00 \%)$ purchased their products directly from the farmers (producers). However, $9.8 \%$ of the wholesalers and $6.2 \%$ of the retailers purchase the products from the rural assemblers. The study also showed that $4.2 \%$ of the wholesalers and $71.8 \%$ of the retailers obtained their products from wholesalers. The results of the marketing channels for banana and plantain fruits showed that both the wholesalers and retailers purchased their banana and plantain directly from the producers, while, some of the wholesalers purchased from on-farm collectors or the rural assemblers. In urban centres, the wholesalers sell to the retailers who in turn resell smaller quantities to the ultimate consumers.

\begin{tabular}{|c|c|c|c|c|c|c|c|}
\hline $\begin{array}{l}\text { Sales Income } \\
\text { (\#) }\end{array}$ & Freq. & $\begin{array}{ll}\text { Proportion } & \text { of } \\
\text { Frequency } & (\mathrm{P})\end{array}$ & $\begin{array}{l}\text { Cumm. Pro. } \\
\text { of Frequency }\end{array}$ & $\begin{array}{l}\text { Total Val- } \\
\text { ue of Sales }\end{array}$ & $\begin{array}{l}\text { Pro. of Total } \\
\text { Value of Sales }\end{array}$ & $\begin{array}{c}\text { Cumm. } \\
\text { Pro. of } \\
\text { Sales (C) }\end{array}$ & PC \\
\hline$\leq 10000$ & 7 & 0.14 & 0.14 & 19200 & 0.015 & 0.015 & 0.002 \\
\hline $10001-20000$ & 11 & 0.22 & 0.36 & 84480 & 0.066 & 0.081 & 0.018 \\
\hline $20001-30000$ & 15 & 0.30 & 0.66 & 218880 & 0.171 & 0.252 & 0.076 \\
\hline $30001-40000$ & 10 & 0.20 & 0.86 & 418560 & 0.327 & 0.579 & 0.116 \\
\hline
\end{tabular}




\begin{tabular}{lrrrrrrr}
$40001-50000$ & 4 & 0.08 & 0.94 & 373760 & 0.292 & 0.871 & 0.070 \\
$>50000$ & 3 & 0.06 & 1 & 165120 & 0.129 & 1 & 0.060 \\
\hline Total & 50 & & 1280000 & & & 0.342 \\
\hline
\end{tabular}

$\mathrm{GC}=1-\sum \mathrm{PC}=1-0.342=0.66$

Source: Researchers' Field Survey (2017)

Table 1. Distribution of banana retailers by monthly sales income

\begin{tabular}{lcccccccc}
\hline $\begin{array}{c}\text { Sales Income } \\
(\#)\end{array}$ & Freq. & $\begin{array}{c}\text { Proportion } \\
\text { Frequency }\end{array}$ & $\begin{array}{c}\text { of } \\
(\mathbf{P})\end{array}$ & $\begin{array}{c}\text { Cumm. Pro. } \\
\text { of Frequency }\end{array}$ & $\begin{array}{c}\text { Total } \\
\text { Value of } \\
\text { Sales }\end{array}$ & $\begin{array}{c}\text { Pro. of Total } \\
\text { Value of Sales }\end{array}$ & $\begin{array}{c}\text { Cumm. Pro. } \\
\text { of Sales (C) }\end{array}$ & \begin{tabular}{c} 
PC \\
\hline$\leq 10000$
\end{tabular} \\
\hline 1 & 0.14 & 0.14 & 38766 & 0.039 & 0.039 & 0.006 \\
$10001-20000$ & 10 & 0.20 & 0.34 & 163016 & 0.164 & 0.203 & 0.041 \\
$20001-30000$ & 16 & 0.32 & 0.66 & 344918 & 0.347 & 0.550 & 0.176 \\
$30001-40000$ & 12 & 0.24 & 0.90 & 346906 & 0.349 & 0.899 & 0.216 \\
$>40000$ & 5 & 0.10 & 1 & 100394 & 0.101 & 1 & 0.100 \\
\hline Total & 50 & & & 994000 & & & 0.539 \\
\hline
\end{tabular}

$\mathrm{GC}=1-\sum \mathrm{PC}=1-0.539=0.46$

Source: Researchers' Field Survey (2017)

Table 2. Distribution of plantain retailers by monthly sales income

\begin{tabular}{|c|c|c|c|c|c|c|c|}
\hline $\begin{array}{c}\text { Sales Income } \\
(\#)\end{array}$ & Freq. & $\begin{array}{lc}\text { Proportion } & \text { of } \\
\text { Frequency } & (\mathbf{P})\end{array}$ & $\begin{array}{c}\text { Cumm Pro. of } \\
\text { Frequency }\end{array}$ & $\begin{array}{c}\text { Total } \\
\text { Value of } \\
\text { Sales } \\
\end{array}$ & $\begin{array}{c}\text { Pro of total } \\
\text { Value of Sales }\end{array}$ & $\begin{array}{l}\text { Cumm. Pro } \\
\text { of Sales (C) }\end{array}$ & PC \\
\hline$\leq 60000$ & 4 & 0.13 & 0.13 & 76137 & 0.048 & 0.048 & 0.006 \\
\hline$\overline{6} 0001-70000$ & 10 & 0.33 & 0.46 & 360067 & 0.227 & 0.275 & 0.091 \\
\hline $70001-80000$ & 8 & 0.27 & 0.73 & 467929 & 0.295 & 0.569 & 0.154 \\
\hline $80001-90000$ & 5 & 0.17 & 0.90 & 233171 & 0.147 & 0.717 & 0.122 \\
\hline 90001-100000 & 2 & 0.07 & 0.97 & 247447 & 0.156 & 0.872 & 0.061 \\
\hline$>100000$ & 1 & 0.03 & 1 & 203033 & 0.128 & 1 & 0.030 \\
\hline Total & 30 & & & 1586200 & & & 0.464 \\
\hline
\end{tabular}

$\mathrm{GC}=1-\sum \mathrm{PC}=1-0.464=0.54$

Source: Researchers' Field Survey (2017)

Table 3. Distribution of banana wholesalers by monthly sales income

\begin{tabular}{|c|c|c|c|c|c|c|c|}
\hline Sales Income (\#) & Freq. & $\begin{array}{ll}\begin{array}{c}\text { Proportion } \\
\text { Frequency }\end{array} & \begin{array}{c}\text { of } \\
(\mathbf{P})\end{array} \\
\end{array}$ & $\begin{array}{c}\text { Cumm Pro. } \\
\text { of Frequency }\end{array}$ & $\begin{array}{c}\text { Total } \\
\text { Value of } \\
\text { Sales } \\
\end{array}$ & $\begin{array}{c}\text { Pro of total } \\
\text { Value of Sales }\end{array}$ & $\begin{array}{l}\text { Cumm. Pro } \\
\text { of Sales (C) }\end{array}$ & $\mathbf{P C}$ \\
\hline$\leq 80000$ & 3 & 0.10 & 0.10 & 51625 & 0.025 & 0.025 & 0.003 \\
\hline $80001-90000$ & 2 & 0.07 & 0.17 & 175526 & 0.085 & 0.110 & 0.008 \\
\hline $90001-100000$ & 6 & 0.20 & 0.37 & 448108 & 0.217 & 0.327 & 0.065 \\
\hline 100001-110000 & 10 & 0.33 & 0.70 & 631894 & 0.306 & 0.633 & 0.209 \\
\hline $110001-120000$ & 8 & 0.27 & 0.97 & 518319 & 0.251 & 0.884 & 0.239 \\
\hline$>120000$ & 1 & 0.03 & 1 & 239541 & 0.116 & 1 & 0.030 \\
\hline Total & 30 & & & 2065016 & & & 0.554 \\
\hline
\end{tabular}

$\mathrm{GC}=1-\sum \mathrm{PC}=1-0.554=0.45$

Source: Researchers' Field Survey (2017)

Table 4. Distribution of plantain wholesalers by monthly sales income

The results of the GC analysis on the distribution of banana and plantain retailers and wholesalers by monthly sales income in Enugu State were shown on Table 1-Table 4. When the GC values were greater than 0.45 and above, there is an indication of inequitable distribution of income. Therefore, calculated GC of 0.66 (from Table 1) and 0.46 (from Table 2) suggested relative high levels of inequitable distribution of income amongst retailers and wholesalers of banana and plantain in Enugu State. Also, calculated GC of 0.54 (from Table 3) and 0.45 (from Table 4) suggested relative low levels of inequitable distribution of income amongst retailers and wholesalers of banana and plantain fruits in rural communities of Enugu State. The tables also indicated that banana exhibited higher inequality in income distribution than plantain at both levels in the rural communities. However, inequalities existed more at retail levels than at wholesale levels for both crops. 


\section{Conclusion}

Efficient and good banana and plantain marketing system operates where there is fully utilized good market structure. Therefore, it is important to understand the economic implications of the market structure of banana and plantain fruits especially in the producer-retailer relationship. It helps in the analysis of banana and plantain chain in rural communities of Enugu State. The study therefore showed the nature of the banana and plantain fruit market and pricing system. The knowledge of marketing channel of banana and plantain influences farmers and middlemen who specialize in production and distribution of the produce, respectively, to strive to operate optimally in the rural communities of Enugu State. Thus, it is necessary for all those involved in the marketing of banana and plantain (producers, marketers, policy-makers and consumers) to know the marketing channel, and how to compute, interpret and apply it on daily basis.

Based on this, concrete decision can then be taken to improve marketing performance of farm produce such as banana and plantain for overall economic growth and development of rural communities in Enugu State, thereby improving the standard of living of the rural dwellers in the state. This study provided information as it concerns banana and plantain marketing structure in Enugu State. The study of banana and plantain marketing inequality provided information on how competitive the markets of banana and plantain were in Enugu State. The study showed that there exists lower inequitable distribution of income among wholesalers than retailers of banana and plantain fruits in the rural communities of Enugu State, Nigeria.

\section{Recommendations}

Based on the findings of the study, the researchers proffered the following recommendations:

a. International donor agencies like Food and Agricultural Organization (FAO) should provide links between prospective banana and plantain farmers, policy makers and researchers to identify and analyze new ways and strategies of encouraging an effective banana and plantain fruit marketing system.

b. Enugu State Government should encourage farmers in rural communities through the efforts of agricultural extension workers to move into commercial production of banana and plantain. This will give room for profitable marketing of the banana and plantain fruits in the state.

c. The state government should reduce the high inequality that exists among retailers by making available adequate credits to banana and plantain producers and sellers at appropriate interest rates.

d. The state government should formulate and implement policies targeted at improving rural infrastructures such as roads. This will go a long way to assist in the proper channeling of banana and plantain fruits from rural to urban communities in Enugu State and even beyond.

e. Enugu State Government in conjunction with local government councils should provide market information outfit that disseminates information timely to banana and plantain fruit marketers for improved marketing structure of banana and plantain fruits.

\section{References}

1. Ashley C, Maxwell S. Rethinking rural development. [cited 2001 August 28]. Available from http://onlinelibrary.wiley.com/doi/10.1111/1467-7679.00141/epdf?r3.

2. Food and Agricultural Organization. Agriculture: towards 2015/2030. Technical interim report. Rome: FAO; 2000.

3. Atchoarena D, Gasperini L. 2003. Education for rural development: towards new policy responses. [cited 2003]. Available from http://www.fao.org/fileadmin/templates/ERP/2013/link_publications/towards_new_policy.pdf.

4. Obetta KC, Okide CC. Rural development trends in Nigeria: problems and prospects. [cited 2011]. Available from https://www.academia.edu/11203001/Rural_Development_Trends_In_Nigeria_Problems_And_Prospects.

5. Obetta KC, Okide CC. Population education: A strategy for meeting the challenges of rapid population growth on rural development in Nigeria. [cited 2011]. Available from http://globalacademicgroup.com/journals/nard/POPULATION\%20EDUCATION.pdf.

6. Ogidefa I. Rural development in Nigeria: Concept, approaches, challenges and prospect. [cited 2010]. Available from http://socyberty.com=issues=rural-development-in-nigeria-concept-approaches-challenges-and-prospcct/.

7. World Bank. World development report. Washington, DC.: The World Bank; 2007.

8. Federal Ministry of Finance and National Food Reserve Agency. Nigerian state platform-enhancing agricultural growth in core state in African Region: Project Information Document. Report NO. AB2617. Abuja: Federal Min- 
istry of Finance/National Food Reserve Agency; 2008.

9. Obetta AE, Taru VB. The structure of banana and plantain marketing in Enugu State, Nigeria. [cited 2018]. Available from http://aksuagriceconsextjournals.org/index.php/aksujaeerd/issue/view/1

10. Achike AI, Okoroafo UU, Mkpado M. Community empowerment via economic and technical assistance with hybrid plantain/banana enterprise expansion programme in Rivers State, Nigeria. Agro-science J. Trop. Agric., Food, Environ. Ext 2011, 10: 35 - 41.

11. Ajayi AR, Mba GO. Identification of indigenous ripening technologies of banana and plantain fruits among women-marketers in South-Eastern Nigeria. Agro-science J. Trop. Agric., Food, Environ. Ext 2007, 6: 60 - 66.

12. Honfo FG, Tenkouano A, Coulibaly O. A comparative study on banana and plantain-based foods consumption by children and mothers in Cameroon and Southern Nigeria. African J. Food Sci 2011, 5: 257 - 291.

13. Taleke A. Analysis of rice profitability and marketing chain: the case of FograWoreda, South Gondar Zone, Amhara National Regional State, Ethiopia. [MSc thesis].Haramaya: University of Haramaya, Ethiopia; 2010.

14. Mussema R. Analysis of red pepper marketing: the case of Alaba and Siltie in SNNPRS of Ethiopia. [MSc thesis].Haramaya: University of Haramaya, Ethiopia; 2006.

15. Olukosi JO, Isitor SV. Introduction to agricultural market and price: principles and applications. Zaria: Agitab Publishers; 1990.

16. Adegeye AJ, Dittoh JS. Essentials of agricultural economics. Ibadan: Impact Publishers (Nigeria) Ltd; 1985.

17. Ayinde OE, Adewumi MO, Ojehomon VET (editors). Determinants of technical efficiency and varietal-gap of rice production in Nigeria: a meta-frontier model approach. International Association of Agricultural Economists Conference; 2009 August 16-22; Beijing, China.

18. Akinyemi S, Aiyelaagbe I, Akyeampong E. Plantain (Musa Spp.) cultivation in Nigeria: a review of its production, marketing and research in the last two decades. Ibadan: National Horticultural Research Institute; 2010.

19. Chukwu EU, Effects of post-harvest injury on shelf-life and extrusion processing of Musa spp. fruit. [PhD thesis]. Ibadan: University of Ibadan; 1997.

20. Ndaghu AA, Taru VB, Isah JA. Structure and conduct of vegetable marketing in KwandomYamaltu-Deba Local Government Area of Gombe State. Global J. Agric. Sci 2011, 10: 71-75. 